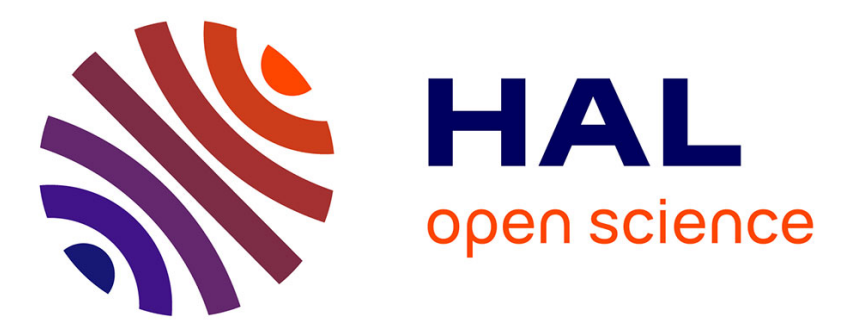

\title{
Responses to reductions in kernel number or to defoliation in collections of winter wheats
}

Jean-François Ledent, Volkmar Stoy, Didier Ramet, Helena Airaksinen, Thomas Patkai

\section{- To cite this version:}

Jean-François Ledent, Volkmar Stoy, Didier Ramet, Helena Airaksinen, Thomas Patkai. Responses to reductions in kernel number or to defoliation in collections of winter wheats. Agronomie, 1985, 5 (6), pp.499-504. hal-00884777

\section{HAL Id: hal-00884777 https://hal.science/hal-00884777}

Submitted on 1 Jan 1985

HAL is a multi-disciplinary open access archive for the deposit and dissemination of scientific research documents, whether they are published or not. The documents may come from teaching and research institutions in France or abroad, or from public or private research centers.
L'archive ouverte pluridisciplinaire HAL, est destinée au dépôt et à la diffusion de documents scientifiques de niveau recherche, publiés ou non, émanant des établissements d'enseignement et de recherche français ou étrangers, des laboratoires publics ou privés. 


\title{
Responses to reductions in kernel number or to defoliation in collections of winter wheats
}

\author{
Jean-François LEDENT \& Volkmar STOY* \\ with the collaboration of Didier Ramet, Helena Airaksinen \& Thomas PatkaI \\ Université Catholique de Louvain, ECOP, 2, place Croix-du-Sud, B-1348 Louvain-la-Neuve, Belgique \\ * Biological Department, Svalöf AB, S-26800 Svalöv, Sweden.
}

The effects on kernel weight of removing all spikelets except the central 4 and of removing flag leaves were measured in two years in the field on 33 modern cultivars in Belgium and on a collection of 25 genotypes including old and modern genotypes in Sweden.

Removing spikelets increased the weight of the remaining kernels in most varieties in all years. The responses differed among varieties and were not consistent among years. Kernel weight responded more to defoliation or spikelet removal in modern than in old varieties. Although potential kernel weight (defined as kernel weight in ears reduced to their 4 central spikelets) was strongly affected by seasonal effects, it was less subject to environmental variations than was kernel weight. Kernel weight response to spikelet trimming or defoliation was not related to source characters or to yield/ha.

Low but significant correlations of potential kernel weight with ovary size at anthesis suggest kernel weight to be at least partly sink-controlled.

Additional key words : Grain filling, source, sink, potential, kernel weight, Triticum aestivum $L$. défoliation partielle dans des collections de blés d'hiver.

Les effets sur le poids sec moyen par grain de l'enlèvement de tous les épillets, à l'exception des 4 épillets centraux, ainsi que les effets de l'enlèvement de la dernière feuille ont été étudiés. Les mesures ont été effectuées 2 années, en champ, sur des séries de 33 cultivars en Belgique et sur une collection de 25 génotypes incluant des variétés anciennes et modernes en Suède. L'enlèvement des épillets augmente le poids des grains restants dans la plupart des cultivars, chaque année. Les effets varient cependant avec les cultivars, de façon différente suivant les années. Les différences de températures ne permettent pas d'expliquer ces différences. Le poids moyen par grain des cultivars modernes est plus influencé par la défoliation ou l'enlèvement d'épillets. Bien que le poids moyen potentiel (défini comme le poids moyen par grain dans les épis réduits à 4 épillets) est fortement affecté par le climat de l'année, il varie moins suivant les saisons que le poids moyen par grain des épis non traités. La réaction du poids moyen par grain aux traitements de défoliations ou d'enlèvements d'épillets n'est pas liée au rendement/ha ni à la taille de la source d'assimilats (surface foliaire, photosynthèse, etc...).

Mots clés additionnels : Remplissage du grain, source, puits, poids potentiel par grain, Triticum aestivum $L$.

\section{INTRODUCTION}

Defoliation and kernel number reduction (by sterilization, floret or spikelet removal) are techniques commonly used to investigate sink and source limitations to grain filling in wheat (Triticum aestivum $\mathrm{L}$.). Flag leaf removal has been shown to decrease both kernel number and kernel weight of wheat : see for instance STOY (1965), LEDENT (1977), PINTHUS \& MilLet (1978), PATTERSON \& BRUN (1980). Decreases in kernel weight (mean weight per kernel at maturity) varied from 0 to $20 \%$ according to genotype (STOY, 1965 ; FISCHER \& HILLERISLAMBERS, 1978) and year (LEDENT, 1977 ; FISCHER \& HILLERISLAMBERS, 1978).

The effects of reducing kernel number vary also with genotypes. In many cases, a decrease in kernel number resulted in an increase in kernel weight and number of grains in remaining spikelets. In some cases and for some varieties, effects of kernel removal on the weight of at least some kernels were nil and negative effects 
have been observed (BREMNER \& RAWSON, 1978; FISCHER \& HILLERISLAMBERS, 1978 ; JENNER, 1979 ; MARTINEZ-CARRASCO \& THORNE, 1979 ; RADLEY \& THORNE, 1981 ; THORNE, 1981 ; SIMMONS et al., 1982).

Most of the studies cited above were conducted on only one or few cultivars. Therefore general conclusions could not be drawn. In one of the most comprehensive studies available (FISCHER \& HILLERISLAMBERS, 1978), 1 to 8 older (tall) cultivars and 8 to 33 newer cultivars were studied during several years. The relative change in kernel weight after treatment (increase after kernel removal, decrease after defoliation) was taken as an index of the degree of source limitation. Source limitation was related to yield but the correlations were relatively weak and there was large year to year and environmental variability. The study was conducted with spring wheat in Mexico and the conclusions may not be applicable to winter wheats and to temperate, humid conditions as found, for example, in North-western Europe. Moreover in the above cited study (FISCHER \& HILleRISLAMBERS, 1978) no attempt was made to relate the source limitation index to characters related to source capacity such as leaf size and leaf duration, or to the duration of grain filling. Leaf size might be important because leaves are sources of carbohydrates and nitrogenous substances.

Our objective was to test in European winter wheats the generality of the effects of kernel removal or defoliation, described in the literature, and to examine if there were varietal differences in the responses which could be related to yield and yield components. Although an understanding of physiological processes involved in the determination of yield and, more particularly, grain filling was beyond the limited scope of this study we examined also the relationships between the effects of these treatments and source size.

\section{MATERIALS AND METHODS}

The trials were conducted at the Plant Breeding Station of Gembloux (Belgium) in 1979 and 1980, and at Svalöf AB in Southern Sweden in 1980 and 1981.

The summer of 1980 was characterized by abnormally high rainfall during June and July. Thus our results were determined over two very different years at each location (table 1).

Only modern cultivars were included in the two trials conducted in Belgium. A sample of $\mathbf{3 3}$ genotypes being evaluated for inclusion in the Belgian national list was used. The genotypes included were not the same in each year, only 6 genotypes being common to both trials. In Sweden, 25 genotypes (the same each year) representing a spectrum of releases dating from the beginning of the century were included. Genotypes were considered as old if released between 1900 and 1953 ; new genotypes were those released between 1968 and 1979.

Plots were $10 \times 1.20 \mathrm{~m}$ with rows $0.2 \mathrm{~m}$ apart in Belgium, and $9.8 \times 1.25 \mathrm{~m}$ with rows $0.12 \mathrm{~m}$ apart in Sweden. In Sweden, there was only one replication available in 1980. Each plot was divided into 4 parts to obtain 4 (unrandomized) blocks. The analyses of variance for that trial were therefore biased. The other trials were conducted as randomized complete blocks with 4 replicates.

In Sweden lodging was prevented with netting held in position over the plots by stakes, and progressively raised during crop growth. Diseases were controlled with fungicides.

Nitrogen was applied in the spring in 3 split applications in Belgium (100 kg/ha total) and in 2 split applications $(90 \mathrm{~kg} / \mathrm{ha}$ total in $1980 ; 120 \mathrm{~kg} / \mathrm{ha}$ in 1981) in Sweden. In Belgium the soil was a loam with argilic horizon classified as an alfisol. In Sweden the soil was a medium clay (inceptisol). Harvests were in mid August in Belgium and between 18 and 27 August in Sweden.

Morphological characters such as the size (length, width, area, dry weight) of each of the 3 uppermost leaves were determined at anthesis on 10 (Belgium) or 5 (Sweden) randomly selected ear-bearing shoots per plot. Leaf area was measured with an electronic leaf area meter. Length and dry weight of stem sections were determined at anthesis and 15 days later. The fresh weight of ovules from the 2 basal florets in a central spikelet were determined in 10 shoots at anthesis (in the Swedish trials only). Yield per spike, number of kernels, number of spikelets, and kernel weight were measured on 10 (Belgium) or 20 (Sweden) shoots per plot.

Sequential ratings of leaf senescence were made to determine leaf duration. The ratings were based on visual estimations of percentage of the surface area being green, yellow, or necrotic. End of grain filling was determined by the absence of eosin coloration in spikes after 2 hours with peduncles dipped in an eosine solution (FEIFFER et al., 1977). At maturity the vascular connections between ear and culm get plugged and eosin coloration cannot penetrate into the ear. In Sweden, carbon dioxide exchange rate (CER) in the upper leaves was measured repeatedly in the field with a rapid ${ }^{14} \mathrm{CO}_{2}$ method developed by SHIMSHI (1969).

Final yields were determined from whole plots, except in Sweden, 1981, where half plots were used.

At anthesis (determined separately for each genotype) 10 (Belgium) or 5 (Sweden) groups of 3 shoots with ears of roughly equal length were tagged in each plot. In each group one shoot was left untreated, one had its flag leaf lamina removed and the ear of the last one was trimmed. The number of fertile spikelets on intact ears was between 14 and 20 in all trials. Only the 4 central spikelets were left in trimmed ears. These, in the case of ears with 18 fertile spikelets were spikelets numbered 7 through 10 counted from the spike base. The rachis above the uppermost remaining spikelet was cut and lower spikelets were trimmed.

At maturity kernel weight and kernel number were determined. In Sweden weights of the 2 proximal kernels and of the distal kernels of the 4 central spikelet were measured in all treatments. Number and weight of grains in the whole of ears of untreated and defoliated shoots was also measured. In Belgium grains of 4 spikelets were weighted in trimmed and control ears and of all grains in ears of control and defoliated shoots. Potential kernel weight was defined as kernel weight (mean weight per kernel) in the grains of trimmed ears.

Percentage enhancement was defined as the differ- 
ence between potential kernel weight and kernel weight in the central spikelets of controls (control kernel weight), expressed as a percentage of control kernel weight.

Means for each plot were subjected to analysis of variance per treatment and year separately. Correlations between characters were calculated from the variety means. Data for both years were used for analyzing the effect of years and the possible interactions between year (season) and varieties. In Belgium this analysis was limited to the 6 varieties used in both years. In Sweden all varieties were used each year and the analysis included them all.

\section{RESULTS AND DISCUSSION}

\section{A. Climatic data and crop characters}

Precipitation in 1980 was abnormally high for June and July over Northern Europe: precipitation for these 2 months were $83 \mathrm{~mm}$ and $283 \mathrm{~mm}$ (Belgium 1979,1980 ) and $293 \mathrm{~mm}, 159 \mathrm{~mm}$ (Sweden 1980, 1981). Corresponding mean temperatures were 16.3 , $15.4,16.1$ and $15.4^{\circ} \mathrm{C}$. Mean number of shoots $/ \mathrm{m}^{2}$ was 431 (Belgium) and 488 or 504 (Sweden ; corresponding standard deviations were 57,45 and 54).

Total final plant height varied from 75 to $103 \mathrm{~cm}$ in the Belgian trials and from 65 to $143 \mathrm{~cm}$ in the Swedish trials. In Sweden the height varied from 110 to $143 \mathrm{~cm}$ for the 10 older varieties (introduced before 1953) and from 65 to $112 \mathrm{~cm}$ for the others. Average duration of grain filling was 63 days (Belgium 1978 and 1979) and 49 or 55 days (Sweden 1980, 1981). Yield levels (grain weight $16 \%$ moisture) were mostly between 5000 and $7000 \mathrm{~kg} / \mathrm{ha}$.

\section{B. Response of kernel weight to spikelet removal or defoliation}

Kernel weight increased in trimmed ears (relatively to the controls) (table 1) but there were some individual exceptions where kernel weight in trimmed ears were less than in controls. The treatment affected both distal and proximal kernels and did not alter the ratio between their kernel weights (74-80 \% on an average). Moreover in treated ears kernel weight of proximal kernels was closely related to kernel weight of distal kernels $\left(r=0.82^{* *}, 0.88^{* *}\right.$ for 1980,1981 respectively, Sweden). Hence data for distal and proximal grains are not presented separately in table 1 . Percentage enhancement in individual varieties ranged from -6 to +58 .

Flag leaf removal at anthesis decreased kernel weight by 2 to $27 \%$. These results agree with those presented in FISCHER \& HILLERISLAMBERS (1978) and LEDENT (1979). The effects on proximal and distal kernel weight were comparable, and significantly correlated $\left(r=0.60^{* *}\right.$, Sweden 1980).

\section{Difference of response among varieties}

There were significant differences among cultivars for potential kernel weight (fig. 1), kernel weight of intact ears and percentage enhancement of kernel weight (fig. 3) in all years. Years $\times$ cultivars interactions were significant $(p \leqslant 0.01)$ for the three parameters, in Sweden.

In Belgium significant interactions ( $p \leqslant 0.05$ ) were limited to potential kernel weight, but the interactions could only be calculated for the 6 cvs common to both years. Significant interactions $(p \leqslant 0.01)$ with year (season) were also found for the comparison of old and new cultivars in Sweden. In 1980 kernel weight of modern cultivars increased more due to spikelet removal than in the older, taller genotypes. Significant $(p \leqslant 0.01)$ differences between old and new cultivars were found for all 3 parameters studied. The following year the differences were smaller (table 1) and not significant $(\mathrm{p} \leqslant 0.05)$.

Hence the existence of significant differences among cultivars for the effect of kernel removal is confirmed

TABLE 1

Effect of a reduction of spikelet number at anthesis on kernel weight.

Effet de la réduction du nombre d'épillets à la floraison sur le poids sec moyen par grain.

\begin{tabular}{|c|c|c|c|c|c|c|c|c|}
\hline & & \multicolumn{2}{|c|}{$\begin{array}{l}\text { Potential kernel weight }{ }^{a}(\mathrm{mg}) \\
\text { Poids moyen potentiel par grain }\end{array}$} & \multicolumn{2}{|c|}{$\begin{array}{l}\text { Kernel weight }{ }^{a}(\mathrm{mg}) \\
\text { Poids moyen par grain }\end{array}$} & \multicolumn{3}{|c|}{$\begin{array}{l}\text { Percentage enhancement }{ }^{\alpha} \\
\text { Augmentation relative en } \%\end{array}$} \\
\hline & & $\begin{array}{c}\text { old } \\
\text { Variétés anciennes }\end{array}$ & $\begin{array}{l}\text { modern } \\
\text { Variétés modernes }\end{array}$ & old & modern & old & mo & dern \\
\hline \multirow[t]{2}{*}{ Belgium } & 1979 & - & $49(47)^{b}$ & - & 42 & - & 10 & (11) \\
\hline & 1980 & - & $37(35)^{b}$ & - & 31 (27) & - & 13 & (19) \\
\hline \multirow[t]{2}{*}{ Sweden } & 1980 & 44 & 46 & 38 & 34 & 11 & 34 & \\
\hline & 1981 & 47 & 48 & 42 & 43 & 5 & 3 & \\
\hline
\end{tabular}

$a$ Potential kernel weight : mean dry weight of all grains in the 4 spikelets left on trimmed ears.

Kernel weight : mean kernel weight in whole untreated spikes.

Percentage enhancement : difference between potential kernel weight and control kernel weight in \% of control kernel weight. Control kernel weight is kernel weight in 4 central spikelets of untreated spikes.

Poids moyen potentiel par grain : poids moyen par grain de tous les grains dans les 4 épillets centraux laissés sur les épis traités.

Poids moyen par grain : poids moyen par grains de tous les grains des épis non traités.

Augmentation relative en $\%$ : différence entre le poids potentiel et le poids moyen par grain des témoins en $\%$ du poids moyen par grain des témoins. Les mesures sont basées sur les grains situés dans les 4 épillets centraux.

$b$ Data between parentheses are for the 6 varieties present both years.

Les moyennes des 6 variétés présentes les 2 années sont données entre parenthèses. 

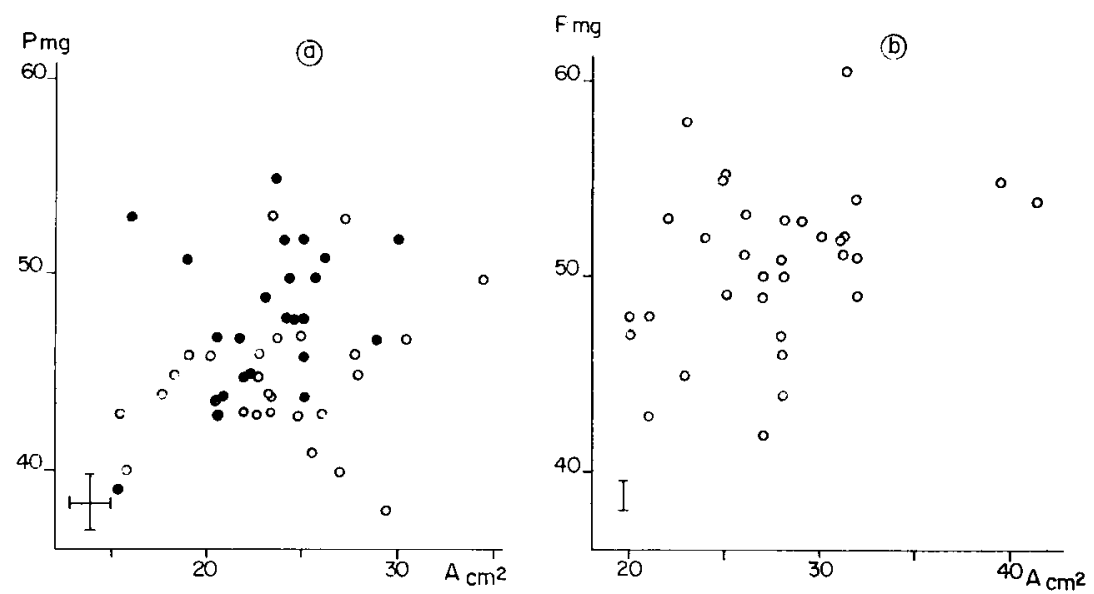

Figure 1

Potential kernel weight $(P)$ (Kernel weight in ears reduced to 4 spikelets) and flag leaf area $(A)$.

Each point corresponds to one genotype.

$+L S D(p \leqslant 0.05)$ least significant deviations

a) Svalov $\circ 1980 ; \cdot 1981$,

b) Belgium Belgique 1979.

but these differences are not stable and limit the interest of the techniques of kernel removal for studying differences among genotypes.

Significant varietal differences were also observed for the effects of defoliations on kernel weight but older and newer varieties responded similarly (in Sweden).

\section{Effects of environment}

Higher percentage enhancements have been reported to be associated with higher temperature (FISCHER \& Hillerislambers, 1978). Comparison of mean percentage enhancements of 10,13,34 and 6 for the two years in Belgium and Sweden respectively (table 1) with corresponding mean temperature for June and July $\left(16.3,15.4,16.1\right.$ and $\left.15.4{ }^{\circ} \mathrm{C}\right)$ does not yield evidence that temperature during grain growth had any major controlling effect on the differences observed among years and location. Differences in temperature among years were relatively limited and years differed much more by their precipitation. The abnormally high precipitation observed in 1980 over Northern Europe contributed very probably to the strong seasonal effects observed. Large rainfall in 1980 has been reported to be associated with poor soil structure, washing off of nutrients and a more general occurrence of lodging and diseases. The two latter factors should only have played a minor role in Sweden where not only diseases but also lodging was prevented. It is possible that control of diseases by fungicides might have been less effective in 1980 . Visual observations of diseases did not clearly support this hypothesis, however.

Consideration of means observed in the two years (table 1) supports the view (FISCHER \& HILLERISLAMBERS, 1978) that potential kernel weight is less subject to environmental variation and therefore more stable than kernel weight. Moreover correlations among varietal means obtained in Sweden one year with corresponding means obtained the following year were

Poids potentiel moyen par grain $(P)$ (c'est-à-dire poids moyen par grain dans les épis réduits à 4 épillets) et surface de la dernière feuille $(A)$.

Chaque point correspond à un génotype.

$\dashv$ p.p.d.s. $(p \leqslant 0,05)$ plus petite différence significative.

higher for potential kernel weight $\left(r=0.68^{* *}\right)$ than for kernel weight $(r=0.38 \mathrm{~N}$.S. $)$.

Seasonal effects on percentage enhancement were reported to be associated with opposite effects on kernel weight of untreated ears (FISCHER \& HILlERISLAMBERS, 1978). This was consistent with the comparison of years in Sweden. This negative association was not only a seasonal effect, however. Correlations of percentage enhancement with average kernel weight, calculated over variety means in Sweden were $-0.58^{* *},-0.54^{* *}$ for 1980,1981 , respectively (percentage enhancement and kernel weight were observed on different samples).

\section{E. Relationship with yield}

No relationship with yield $/ \mathrm{m}^{2}$ was found. A selection of results is presented in figure 2 . Correlations between yield $/ \mathrm{m}^{2}$ and potential kernel weight were $\mathrm{r}=-0.30$ N.S., 0.17 N.S. (Sweden, 1980, 1981 respectively) and $\mathrm{r}=-0.02 \mathrm{~N}$.S., 0.29 N.S. (Belgium, 1979,1980 ). Correlations of yield $/ \mathrm{m}^{2}$ with percentage enhancement were also not significant. No correlation between the reductions of kernel weight due to defoliation and any yield components were consistently observed. Potential kernel weight was significantly related to kernel weight in Belgium $\left(r=0.67^{* *}, 0.58^{* *}\right.$ in 1979 and 1978 respectively). In Sweden the correlation was significant only one year $(r=0.25$ N.S. and $0.61^{* *}$ in 1980,1981 respectively). There was no consistent relationship with other yield components (kernel number/ear ; number of ears $/ \mathrm{m}^{2}$ ).

\section{F. Relationship with source limitation}

Kernel weight response to spikelet trimming was not related to size or activity of photosynthetic surface (source) as measured by flag leaf area, flag leaf duration, duration of grain filling or CER. Correlation between potential kernel weight and flag leaf area were 

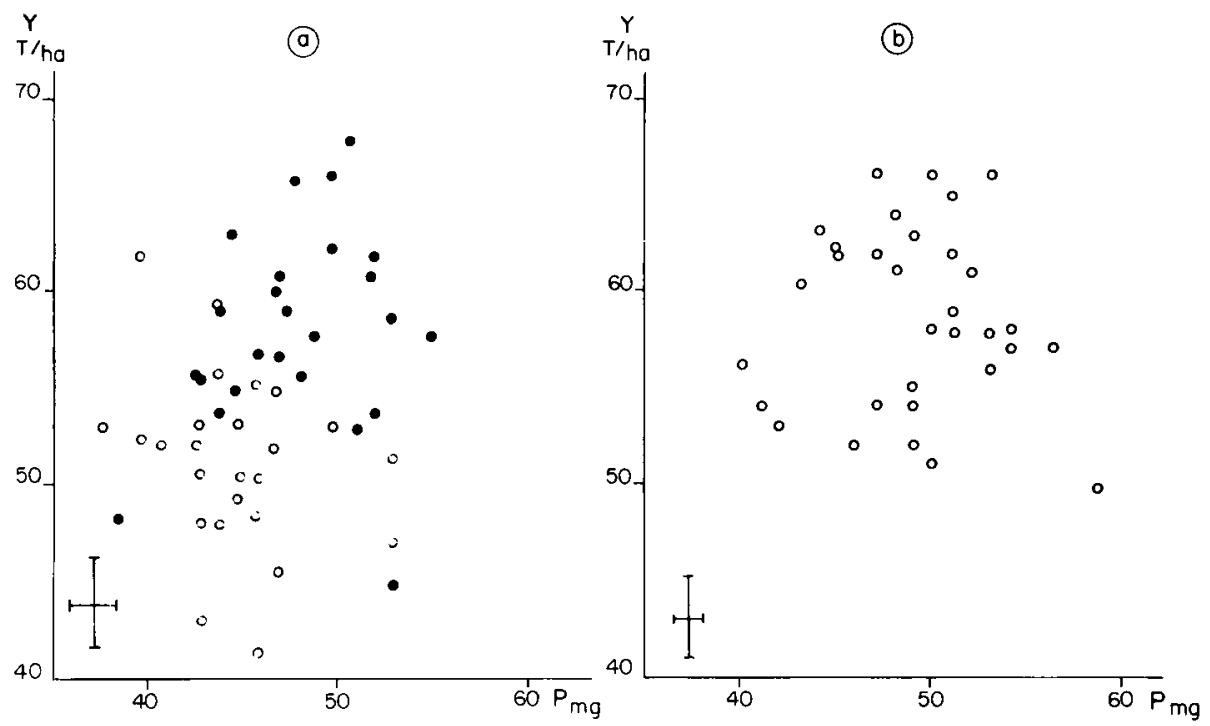

Figure 2

Yield/ha $(Y)$ and potential kernel weight $(P)$.

Rendement/ha (Y) et poids potentiel moyen par grain ( $P$ ).

a) Svalov $01980 ; \cdot 1981$,

b) Belgium Belgique 1979

$r=0.20$ N.S., $r=0.43$ N.S. in Sweden (for 1980, 1981 respectively) and $r=0.35$ N.S. in Belgium (1979) (fig. 1). Similarly the reduction of kernel weight due to defoliation was not correlated with flag leaf size. Moreover there was practically no relationship between the effects of spikelet removal and the effects of defoliations (fig. 3).

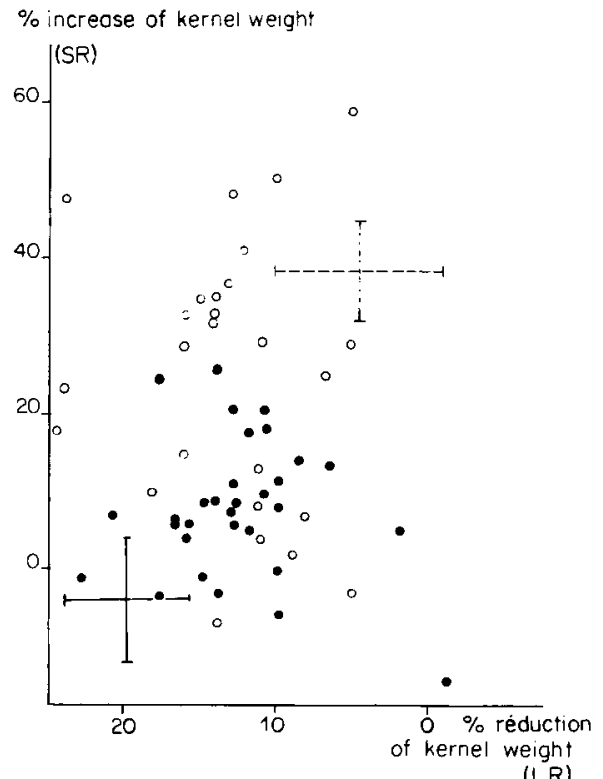

Figure 3

Percentage increase of kernel weight due to spikelet removal (SR) and percentage reduction of kernel weight due to flag leaf removal (LR).

These percentages are the differences between kernel weight in treated ears and controls (in \% of control kernel weight).

- Svalov 1980; - Belgium - Belgique 1979.

Augmentation (en p. 100) du poids moyen par grain, due à l'enlèvement de certains épillets (SR) et réduction (en p.100) due à l'enlèvement de la dernière feuille (LR).

Ces pourcentages correspondent aux différences entre le poids par grain dans les épis traités et celui des témoins, exprimé en p. 100 des témoins.
The lack of correlation between response to spikelet removal and defoliation, the absence of relationship with size or activity of photosynthetic surface indicate either that factors other than those related to the source were playing an important role or that spikelet removal was not a valid method for measuring source limitation due to unforeseen consequences of trimming or defoliation (JENNER, 1980). Effects of the treatments applied are not limited to effects on carbohydrate accumulation in the grain. Kernel number reduction also effects the movement of nitrogen to the grain (LEDENT, 1977 ; SIMMONS \& MOSS, 1978 ; JENNER, 1979 ; RADLEY \& THORNE, 1981 ; THORNE, 1981). Differences in sink capacity at the level of individual kernel were among the factors likely to be of importance, as suggested by the early determination of potential kernel weight.

Indeed, potential kernel weight (determined on proximal kernels in treated ears) as well as weight of distal kernels in trimmed ears, were correlated with fresh weight of carpels at anthesis (ovary size). Thus the early determination of differences in kernel weight proposed in BINGHAM (1967) was verified for potential kernels weight as in FISCHER \& HILLERISLAMBERS (1978). The correlations were not high, however : $\mathrm{r}=0.32 \mathrm{~N} . \mathrm{S}$. and $0.52^{* *}$ for proximal kernels, and $\mathrm{r}=0.52^{* *}$ and $0.48^{* *}$ for distal kernels $(1980,1981$ respectively). Measurements of ovary size were taken in Sweden only.

\section{CONCLUSIONS}

The techniques used in this study (spikelet removal and defoliation) are simple and suitable for examining large collections of genotypes. There is some generality in the type of response to these treatments since European winter wheats gave results comparable to those found in earlier studies. Varietal and seasonal effects were observed but their interaction limits the 
practical interest of the methods used for examining collections of genotypes. Of interest was, however, the greater difficulty of modern Swedish varieties to reach their potential kernel weight under less favourable conditions of 1980 as indicated by their percentage enhancement which was higher than in older cultivars.

The lack of correlation between percentage increase in kernel weight and yield is a further restriction to their practical value. Finally the influence of factors other than those related to the source of carbohydrates complicates the interpretation of results.

Grain filling and yield are obviously determined by a whole array of interrelated factors (see for instance
STOY, 1965, 1980 ; MiChAEL \& BERINGER, 1980) and a detailed investigation of the complexity of the process is beyond the simplicity of the crude techniques used here.

Reçu le 9 avril 1984. Accepté le 25 janvier 1985.

\section{ACKNOWLEDGEMENTS}

The authors thank Noulard L. and Vandam J. of the Plant Breeding Station of Gembloux (Belgium) for the permission to use their field plots, and Svalöf $\mathrm{AB}$ (Sweden) for financial support of the Swedish field experiments.

\section{REFERENCES}

Bingham J., 1967. Investigations on the physiology of yield in winter wheats, by comparisons of varieties and by artificial variation in grain number per ear. J. Agric. Sci., Camb., 68, 411-422.

Bremner P. M., Rawson H. M., 1978. The weights of individual grains of the wheat ear in relation to their growth potential, the supply of assimilate and interaction between grains. Aust. J. Plant Physiol., 5, 61-72.

Feiffer P., Lohse G., Unger W., 1977. Enige neue Aspekte zur Getreideernte. Feldwirtschaft, 18, 254-256.

Fischer R. A., Hillerislambers D., 1978. Effect of environment and cultivar on source limitation to grain weight in wheat. Aust. J. Agric. Res., 29, 443-458.

Jenner C. F., 1979. Grain filling in wheat plants shaded for brief periods after anthesis. Aust. J. Plant Physiol., 6, 629-641.

Jenner C. F., 1980. Effects of shading or removing spikelets in wheat : testing assumptions. Aust. J. Plant Physiol., 7, 113-121.

Ledent J. F., 1977. Effect of partial defoliation and vein cutting on grain growth and yield in winter wheat (Triticum aestivum L.). Bull. Soc. Roy. Bot. Belg., 110, 230-250.

Martinez-Carrasco R., Thorne G. N., 1979. Effects of crop thinning and reduced grain numbers per ear on grain size in two winter wheat varieties given different amounts of nitrogen. $A n n$. Appl. Biol., 92, 383-393.

Michael E., Beringer H., 1980. The role of hormones in yield formation, 85-116. In Van Diest A. : 'Physiological aspects of crop productivity'. Proc. of the $15^{\text {th }}$ Colloquium of the International Potash Institute held in Wageningen, The Netherlands. International Potash Institute. Worblaufen-Bern.

Patterson T. G., Brun W. A., 1980. Influence of sink removal in the senescence pattern of wheat. Crop Sci., 20, 19-23.
Pinthus M. J., Millet E., 1978. Interactions among number of spikelets, number of grains and grain weight in the spikes of wheat (Triticum aestivum L.). Ann. Bot., 42, 839-848.

Radley M. E., Thorne G. N., 1981. Effects of decreasing the number of grains in ears of cvs 'Hobbit' and 'Maris Huntsman' winter wheat. Ann. Appl. Biol., 98, 149-156.

Shimshi D., 1969. A rapid field method for measuring photosynthesis with labelled carbon dioxide. J. Exp. Bot., 20, $381-401$.

Simmons S. R., Moss D. N., 1978. Nitrogen and dry matter accumulation by kernels formed at specific florets in spikelets of spring wheat. Crop Sci., 18, 139-143.

Simmons S. R., Crookston R. K., Kurle J. K., 1982. Growth of spring wheat kernels as influenced by reduced number per spike and defoliation. Crop Sci., 22, 983-988.

Stoy V., 1965. Photosynthesis, respiration and carbohydrate accumulation in spring wheat in relation to yield. Physiologia Plant., Supplementum IV, 1-125.

Stoy V., 1980. Grain filling and the properties of the sink, 65-76. In Van Diest A. : "Physiological aspects of crop productivity". Proc. of the $15^{\text {th }}$ Colloquium of the International Potash Institute held in Wageningen, The Netherlands. International Potash Institute. Worblaufen-Bern.

Thorne G. N., 1981. Effects on dry weight and nitrogen content of grains of semi-dwarf and tall varieties of winter wheat caused by decreasing the number of grains per ear. Ann. Appl. Biol., 98, 355363. 